he should retain it for his own use. To this was added a further 200l. a year for maintenance, and a pension of $50 l$. a year to Caroline Herschel. And besides, he was allowed to make specula for sale, and half the observatories of Europe were so furnished by him at prices which were then thought considerable.

At any rate Herschel jumped at the offer, which, by relieving him from his musical slavery, allowed him to follow the wish of his life. The Herschels then came to the neighbourhood of Windsor, and after several removals they finally settled at Slough. The change was delightful for him, since he now had space for his telescopes and workshops, but the difficulties of housekeeping in a rambling and dilapidated house rendered the change somewhat less agreeable to his sister.

The closeness to Windsor was perhaps a necessity of the case, but it had its disadvantages, since he was frequently summoned to take his telescope to Windsor, or large parties from the Castle would visit him at his house in order to see the wonders of the heavens. When his time had been wasted in this way he would make up for the loss by redoubled labour.

The fury, as I may call it, with which they worked may be gathered from Caroline's journal, and the work was not free from danger, because in his eagerness Herschel would not always delay his observations until the telescope was properly fixed. To stand in the dark on a platform without a railing, when your attention is distracted from your position, cannot be very safe, and they both met with a good many accidents which might easily have proved fatal.

The incessant work, together with the interruptions by the visitors from the Castle, began at length to tell on Herschel's health. His sister notes that on October 14, r806, after working all day, he was out from sunset unitil past midnight surrounded by fifty or sixty persons, without food or proper clothing, and that he never seemed to recover completely from this great strain on his strength.

But I have passed by an event of importance in the lives of both brother and sister, for in 1783 he married Mrs. Pitt, a lady of singularly amiable and gentle character. To the sister, however, the marriage was a great blow, for, although she continued to be his secretary and assistant, she moved into neighbouring lodgings, and was no longer so closely associated with him as theretofore. Mrs. John Herschel writes: "It is not to be supposed that a nature so strong and a heart so affectionate should accept the new state of things without much and bitter suffering," and tradition confirms this belief. All her notes and memoranda relating to a period of fifteen years from the time of the marriage were destroyed by her when, as we may presume, her calmer judgment showed her that the record of her heartburning would be painful to the surviving members of the family. At any rate, she was on affectionate terms with her sister-in-law throughout all the later years of her life, and the brilliant career of her nephew, the celebrated Sir John Herschel, and correspondence with him, afforded the leading interest of her old age.

Although Herschel lived until 1822 , and accomplished an enormous amount of work up to the end of his life, yet his health seems to have declined from about the time I have noted. On his death Caroline felt that her life, too, was practically ended, and she returned to Hanover. Ever afterwards she used to cry, "Why did I leave happy England?" and it is incomprehensible that she should not have returned to the place where all her real interests lay.

Although she felt the death of her brother as practically the end of her life, she was always full of jokes and fun. In a letter to her nephew, she told him that her father used to punish her, a grown woman, by depriving her of her pudding if she did not guess rightly the angle of the piece she had helped herself to. Dr. Groskopf writes of her when she was eightynine years of age, "Well! what do you say of such a person being able to put her foot behind her back and scratch her ear with it, in imitation of a dog, when she was in one of her merry moods." She only died in 1847 , having very nearly completed her ninetyeighth year.

Herschel himself must have been a man of singular charm, as is testified to by Dr. Burney and his daughter, Mdme. d'Arblay. That he possessed an incredible amount of patience is proved by the fact of his submitting to the reading aloud of the whole of a portentous, and fortunately unpublished, poem in many cantos by Dr. Burney, entitled "A Poetical History of Astronomy." It appears that Herschel had had an interview with Napoleon in Paris in 1802 , and the poet Campbell asked him whether he had been struck by Napoleon's knowledge. "No," said Herschel, "the First Consul surprised me by his versatility, but in science he seemed to know little more than any welleducated gentleman, and of astronomy much less, for example, than our King. His general air was something like affecting to know more than he did know.' $\mathrm{He}$ was struck, too, by Napoleon's hypocrisy in observing "how all these glorious views gave proofs of Almighty Wisdom."

And now having endeavoured to show what kind of people Caroline and her brother were, I must turn to what they did. Herschel's discoveries were so numerous that I am compelled to make a selection. I shall, therefore, only attempt to sketch his endeavour to understand the general construction of the stellar universe and to speak of his work on double stars.

(To be continued.)

\section{BUDGETS OF CERTAIN UNIVERSITIES AND UNIVERSITY COLLEGES.}

$T H E$ reports for the year IgIo-ri from those universities and university colleges in Great Britain which are in receipt of grants from the Board of Education have now been issued as Bluebooks (Cd. 6245 and 6246).

It will be remembered that the following English universities participate in the annual grant made by Parliament for university colleges:-Birmingham, Bristol, Durham (Armstrong College), Leeds, Liverpool, Manchester, Sheffield, London (including University College, King's College, Bedford College, School of Economics, and East London College), and also the University Colleges at Nottingham, Reading, and Southampton. The University of Wales includes the University Colleges of Aberystwyth, Bangor, and Cardiff.

The reports also deal with certain other constituent colleges of universities in receipt of aid under "The Statement of Grants available from the Board of Education in Aid of Technological and Professional Work in Universities in England and Wales." These institutions are twelve in number, nine being medical schools attached to hospitals in London. They are all schools of the University of London. One, the Newcastle College of Medicine, is a constituent college of the University of Durham, while the two remaining, namely, Manchester Municipal School of Technology and the Bristol Merchant Venturers' College, make provision for the faculties of technology and engineering, respectively, in the universities to which they are attached. 
The tabular matter which is contained in the volumes gives full information as to the income and expenditure of the institutions concerned. To make a comparison with the reports of previous years easily possible, the data concerning the medical schools and other colleges receiving grants from the Board of Education in aid of technological and professional work, as explained above, are printed in italics in the tables and not included in the reports.

The following summaries of income and expenditure have been drawn up from the tables, and serve to bring out the resources of the institutions of higher education participating in the Treasury grant, and the way the available funds are expended.

Universities and University Colleges, iglo-I 1 . (x) ENGLAND.

(a) Income.

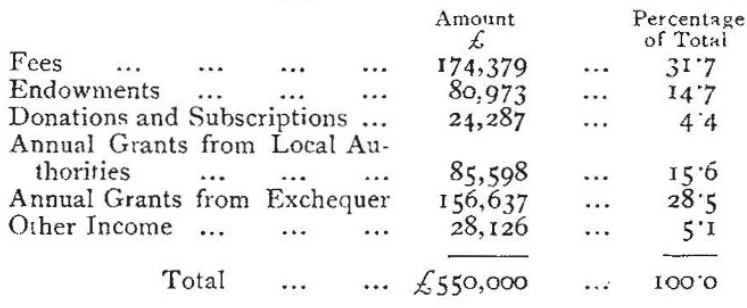

(b) Expenditure.

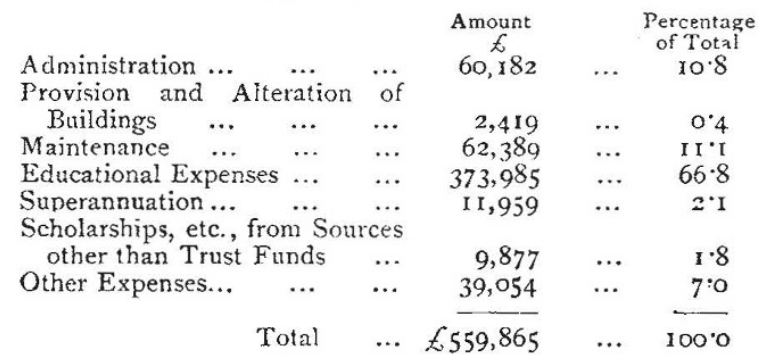

(2) WALES.

(a) Income,

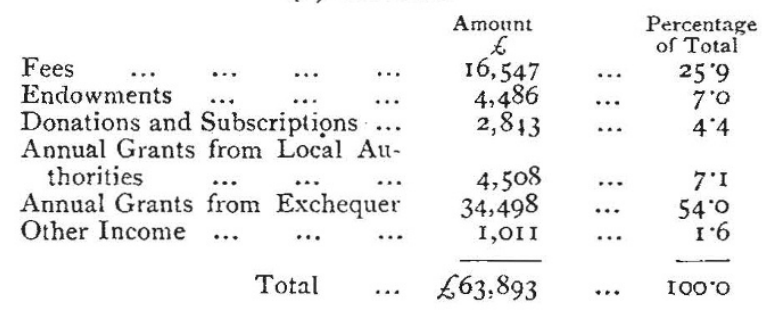

\section{(b) Expenditure.}

\begin{tabular}{|c|c|c|c|c|c|}
\hline \multirow{3}{*}{\multicolumn{2}{|c|}{$\begin{array}{l}\text { Administration } \ldots \\
\text { Provision and Alteration }\end{array}$}} & \multicolumn{2}{|r|}{$\underset{f}{\text { Amount }}$} & \multicolumn{2}{|r|}{$\begin{array}{l}\text { Percentage } \\
\text { of Total }\end{array}$} \\
\hline & & & & $\cdots$ & \\
\hline & & of & & & \\
\hline Buildings $\quad \ldots$ & $\ldots$ & $\cdots$ & - & ... & - \\
\hline Maintenance $\quad \ldots$ & $\cdots$ & $\cdots$ & 3.705 & $\ldots$ & $5 \cdot 8$ \\
\hline Educational Expen & $\ldots$ & $\ldots$ & 45,852 & $\ldots$ & $7 \mathrm{I} \cdot 8$ \\
\hline Superannuation .... & $\cdots$ & $\cdots$ & I,946 & $\cdots$ & $3^{\circ} \mathrm{O}$ \\
\hline \multicolumn{6}{|c|}{ Scholarships, \&c., from sources } \\
\hline $\begin{array}{l}\text { other than Trust } \\
\text { Other Expenses... }\end{array}$ & inds & $\cdots$ & 970 & $\cdots$ & $1 \cdot 5$ \\
\hline \multirow[t]{2}{*}{ Other Expenses... } & $\cdots$ & $\cdots$ & 3,466 & $\cdots$ & $5 * 4$ \\
\hline & tal & $\cdots$ & $£, 63,887$ & & $00^{\circ} \mathrm{O}$ \\
\hline
\end{tabular}

The committee appointed last summer to advise the Board of Education as to the distribution of Exchequer grants available for university education in
England and Wales directed attention to the importance of substantial endowments and the wide divergence that exists in this respect between different institutions. This divergence is brought out by the figures given in the table from which the above summaries were made; thus, while Manchester receives nearly 30 per cent. of its income from endowment, King's College receives only about I per cent. Manchester and Liverpool together have nearly half the total income from the endowments of the universities and university colleges in England which participate in the Exchequer grant. In considering the contribution made by local authorities, it is to be remembered that the London County Council contributes $10,000 l$. to the University of London, besides the various sums paid to the schools of the University. 3ool. of the amount is taken for the administrative expenses of the University, and the remainder is apportioned equally between the four faculties of arts, pure science, engineering, and economics, and is devoted towards the maintenance of certain professorships, readerships, and lectureships in these faculties. The city of Manchester, in addition to its contribution to the University, spends a large sum annually on the Municipal School of Technology. The figures do not include any part of the additional $50,000 l$. voted for the financial year I9II-I2, since none of this increase was distributed until after the end of the period under review in the reports. In addition, the University of London received $8000 l$., the University of Durham 2000l., and the University of Wales $5500 l$., in aid of administrative expenditure, which must otherwise have been met by the constituent colleges from other sources.

The receipts from fees in England amounted to rather less than 32 per cent. of the total income, a decline of I per cent. compared with last year. The amount received from endowment was about the same as last year, namely, ${ }_{5} 5$ per cent.; on the other hand, the receipts from local authorities have increased by i per cent. to $15 \cdot 6$. The total receipts of all kinds from the Exchequer remain about stationary at 28.5 per cent. In Wales, the income from fees increased slightly to 26 per cent.; a further growth is likely to be shown in future returns by reason of the substantial increase that has been made in the fees charged to all students entering Welsh colleges in I9II or later years. The percentage of the income derived from endowments and from local authorities is slightly greater than last year, while the receipts from the Exchequer remain about stationary at 54 per cent.

\section{UNIVERSITY AND EDUCATIONAL INTELLIGENCE.}

Manchester.-By the will of Mr. John Hall the sum of $40,000 l$. is left in reversion to the University During the life of two nieces or the survivor of them Mr. Hall's residuary estate is to be accumulated at compound interest, and on the decease of the survivor the sum of $20,000 l$. is to be devoted to the founding of a Samuel Hall professorship in chemistry, anc I5.00ol to that of a Samuel Hall professorship ir philosophy, it being directed that the holder of this professorship shall deliver once in each year a fref public lecture on the study of philosophy past ane present, to be called the " Hall Oration on Philosophy.' This lecture is to be given in Owens College, Man chester, and is to be of a popular character and suitabl to a general audience. $25 \mathrm{ool}$. has been left for not les than two Samuel Hall scholarships in chemistry: ane $2500 \%$. for not more than two Samuel Hall scholarships it 